Jurnal InFestasi

Vol. 12, No.1, Juni 2016

Hal. 85 - 97

\title{
CORPORATE GOVERNANCE, TAX AVOIDANCE, AUDIT DELAY DAN NILAI PERUSAHAAN (STUDI EMPIRIS PADA PERUSAHAAN PERBANKAN DI BEI PERIODE 2010-2014)
}

\author{
Ronald Tehupuring \\ Pascasarjana Universitas Gadjah Mada, Yogyakarta \\ tehupuringronald@yahoo.co.id
}

\begin{abstract}
Corporate governance is an issue related to the practice of tax avoidance and audit delay and will impact on the value of firm. Application of corporate governance expected to mitigate the asymmetry of information and increase the confidence of shareholders. This study aimed to examine the relationship of corporate governance and tax evoidance practices and their effect on audit delay and firm value. Samples were obtained through purposive sampling and as many as 130 observations, after deducting the data outliers, the final sample of 125 observations 2010-2014 of corporate banking listed on the Indonesian Stock Exchange. The data analysis technique used is multiple linear regression with SPSS version 17.

The results show that the first model: reputation, of KAP, audit quality, and audit committee has no effect on tax avoidance, while independent commissioner negative effect on tax avoidance; The second model suggests that tax avoidance and independent commissioner has no effect on audit delay, while the audit committee negatively affect audit delay; The third model shows that tax avoidance (negative) and the audit committee (positive) effect on the value of firm, while the independent commissioner has not affect on value of firm.
\end{abstract}

Keywords: Corporate Governance, Tax Avoidance, Audit Delay, Firm Value.

\begin{abstract}
Abstrak
Tata kelola perusahaan merupakan isu yang berkaitan dengan praktik penghindaran pajak dan keterlambatan audit dan akan berdampak pada nilai perusahaan. Penerapan tata kelola perusahaan diharapkan dapat memitigasi asimetri informasi dan meningkatkan kepercayaan pemegang saham. Penelitian ini bertujuan untuk menguji hubungan tata kelola perusahaan dan praktik penghindaran pajak serta pengaruhnya terhadap audit delay dan nilai perusahaan. Sampel diperoleh melalui purposive sampling dan diperoleh sebanyak 130 observasi, setelah dikurangi dengan data outlier maka sampel akhir sebanyak 125 observasi perusahaan perbankan periode 2010-2014 yang terdaftar di BEI. Teknik analisis data yang digunakan adalah regresi linear berganda dengan bantuan SPSS Versi 17.

Hasil penelitian model I menunjukkan bahwa reputasi KAP, kualitas audit, dan komite audit tidak berpengaruh terhadap tax avoidance, sedangkan komisaris independen berpengaruh negatif terhadap tax avoidance; model II menunjukkan tax avoidance dan komisaris independen tidak berpengaruh terhadap audit delay, sedangkan komite audit berpengaruh negatif terhadap audit delay; model III menunjukkan tax avoidance (negatif) dan komite audit (positif) berpengaruh terhadap nilai perusahaan, sedangkan komisaris independen tidak berpengaruh terhadap nilai perusahaan.

Kata Kunci : Corporate Governance, Tax Avoidance, Audit Delay, Nilai Perusahaan.
\end{abstract}




\section{PENDAHULUAN}

Isu terkait penghindaran pajak (tax avoidance) merupakan suatu problema yang telah ada sejak peraturan perundang-undangan pajak dikeluarkan (Andreoni et al., 1998; Uadiale et al., 2010; Verbon dan Dijke, 2007). Isu ini lebih terkenal di kalangan wajib pajak badan karena besarnya pajak penghasilan yang harus dibayarkan kepada fiskus (pemerintah), sehingga akan mengurangi laba perusahaan. Pajak merupakan salah satu sumber pendapatan negara yang terbesar dan unsur penting bagi negara dalam menopang anggaran penerimaan negara sehingga laju pertumbuhan dan pelaksanaan pembangunan nasional dapat berjalan dengan baik guna memenuhi kesejahteraan masyarakat. Namun terdapat kendala dalam penerimaan pajak oleh pemerintah yaitu adanya penghindaran pajak (tax avoidance) yang dilakukan oleh wajib pajak yang disebabkan karena pajak merupakan beban bagi wajib pajak karena dapat mengurangi pendapatan atau laba. Banyak penelitian-penelitian dibidang perpajakan berupaya untuk menjelaskan variasi atas tindakan praktik penghindaran pajak (Shevlin dan Shackelford, 2001, Shevlin, 2007; Hanlon dan Heitzman, 2010). Penghindaran pajak memiliki manfaat ekonomis yang menguntungkan bagi perusahaan (Scholes et al., 2009) dan menjadi sumber pembiayaan yang relatif murah (Armstrong et al., 2012). Namun, penghindaran pajak yang agresif dapat menyebabkan adanya denda ataupun hilangnya reputasi perusahaan.

Pada era globalisasi saat ini, perusahaan mulai menerapkan praktik tata kelola perusahaan (corporate governance) untuk meminimalkan risiko bisnis yang mungkin terjadi. Tata kelola perusahaan merupakan suatu sistem atau mekanisme yang mengatur dan mengendalikan perusahaan untuk menciptakan nilai tambah bagi pemangku kepentingan karena dianggap mampu memperkuat posisi daya saing perusahaan secara berkelanjutan dan mengelola sumber daya secara efektif dan efisien, sehingga dapat meningkatkan kepercayaan investor dalam kaitannya dengan akuntabilitas dan pertanggungjawaban.

Tata kelola perusahaan memiliki prinsip-prinsip dasar yang terdiri dari fairness, transparency, accountability, responsibility, dan independency. Fairness berkaitan dengan perlakuan yang setara dalam memenuhi hak pemangku kepentingan yang didasarkan pada peraturan dan perjanjian yang berlaku, transparency berkaitan dengan proses pengambilan keputusan dan keterbukaan informasi yang sesuai dengan kondisi perusahaan, accountability berkaitan dengan pertanggungjawaban manajemen perusahaan atas pengelolan perusahaan secara efektif dan efisien, dan independency berkaitan dengan tidak adanya tekanan atau pengaruh pihak manajemen perusahaan yang tidak sesuai dengan aturan-aturan perusahaan.

Perusahaan sebagai bagian dari wajib pajak memiliki keharusan dalam memenuhi kewajiban pajaknya. Selain itu juga, ketika perusahaan memiliki tata kelola yang baik maka diharapkan dapat memenuhi kewajiban pajaknya. Namun disisi lain perencanaan pajak tergantung pada dinamika tata kelola perusahaan (Friese, 2006) yang artinya bahwa ketika tata kelola perusahaan tidak dijalankan sesuai dengan prinsip- prinsip dasarnya atau kurangnya kontrol terhadap manajemen perusahaan maka praktik penghindaran pajak dapat saja terjadi (Annisa, 2012).

Praktik penghindaran pajak dapat dilakukan baik dengan cara melaporkan tetapi tidak sesuai dengan kondisi yang sebenarnya ataupun dengan cara tidak melaporkan. Celah penghindaran pajak yang dilakukan oleh perusahaan misalkan: (1) ketika adanya transaksi derivatif di luar pasar modal, (2) transaksi saham di luar pasar modal, (3) aktivitas pendanaan melalui hybird instrument, (4) maupun aktivitas pendanaan melalui back to back loan.

Teori keagenan muncul ketika adanya benturan kepentingan antara agen dan prinsipal yaitu pembuatan kontrak atas setiap tindakan dan keputusan agen dalam memakmurkan kesejahterannya dan kesejahteraan prinsipal (Brennan, 1995). Oleh karena 
itu, teori keagenan menjadi dasar dalam penerapan tata kelola perusahaan yang diharapkan memberikan nilai tambah kepada pemegang saham untuk memperoleh keuntungan atas hasil investasi.

Statement of Financial Accounting Concept (SFAC) No. 2 yang dikeluarkan oleh Financial Accounting Standard Board menyatakan bahwa relevansi dan reliabilitas merupakan dua komponen penting dalam pengambilan keputusan sehingga informasi akuntansi menjadi lebih berguna. Agar informasi akuntansi memiliki relevansi maka informasi tersebut harus disampaikan tepat waktu. Pelaporan keuangan yang tepat waktu dan dengan adanya penerapan tata kelola perusahaan dapat memberikan kontribusi kinerja yang efisien bagi pasar modal karena dapat mengurangi asimetri informasi dan meningkatkan keputusan kegunaan informasi bagi investor dan pengguna lainnya karena apabila adanya penundaan pelaporan informasi akuntansi, maka akan mempengaruhi basis investasi dalam perusahaan (Bamber et al., 1993), mempengaruhi reaksi pasar, ketepatan waktu publikasi informasi keuangan auditan, ketidakpastian keputusan yang didasarkan pada informasi yang telah dipublikasi, serta membuka peluang bagi insider trading (Owusu-Ansah, 2000).

Di Indonesia khususnya, perusahaan yang telah terdaftar di Pasar Modal Indonesia harus menyerahkan laporan keuangan tahunan auditan kepada Bapepam-LK yang diatur dalam Undang-Undang No.8 tahun 1995 tentang kewajiban penyampaian publikasi laporan keuangan tahunan auditan yang bersifat wajib selama batas waktu 120 hari dari akhir tahun fiskal sampai dengan diserahkannya laporan keuangan yang telah diaudit oleh Bapepam-LK dan kemudian diganti dengan peraturan baru dengan Nomor X.K2 tentang kewajiban penyampaian laporan keuangan berkala ke BapepamLK selambat-lambatnya akhir bulan ketiga (90 hari) sejak tanggal 30 september 2003. Bapepam-LK sejak 12 Desember 2012 telah berganti namanya menjadi Otoritas Jasa Keuangan (OJK). Masalah penghindaran pajak merupakan salah satu faktor yang turut mempengaruhi waktu penyampaian informasi akuntansi (laporan keuangan tahunan) dan nilai perusahaan. Hal ini dikarenakan dalam merumuskan penghindaran pajak hingga praktik penghindaran pajak membutuhkan waktu karena di satu sisi praktik penghindaran pajak dapat mengurangi biaya dan meningkatkan nilai perusahaan sedangkan di sisi lain pemegang saham tidak memperoleh nilai tambah karena adanya hubungan positif penghindaran pajak dan rent diversion (Desai dan Dharmapala, 2006), sehingga manajemen perusahaan harus mempertimbangkan strategi yang efektif dalam melakukan praktik penghindaran pajak.

Berdasarkan fenomena yang telah dijelaskan sebelumnya, maka peneliti merumuskan masalah sebagai berikut: (1) Apakah reputasi KAP, kualitas audit, komisaris independen dan komite audit memiliki pengaruh terhadap tax avoidance yang dilakukan di perusahaan perbankan di Indonesia? (2) Apakah tax avoidance, komisaris independen, dan komite audit memiliki pengaruh terhadap audit delay di perusahaan perbankan di Indonesia? (3) Apakah tax avoidance, komisaris independen, dan komite audit memiliki pengaruh terhadap nilai perusahaan perbankan di Indonesia?

\section{Corporate Governance}

Tatakelola perusahaan dapat didefinisikan sebagai sistem yang mengatur dan mengendalikan perusahaan untuk menciptakan nilai tambah bagi pemangku kepentingan (Desai dan Dharmapala, 2007). Tata kelola perusahaan muncul untuk memitigasi adanya konflik keagenan antara fiskus dan wajib pajak (manajemen perusahaan). Disatu sisi, fiskus berharap untuk memperoleh penerimaan sebesar besarnya atas pembayaran pajak, sementara di sisi lain wajib pajak berusaha untuk meminimalkan pembayaran pajak dengan cara menghasilkan laba yang cukup signifikan namun membayar beban pajak yang rendah.

Perusahaan yang telah mendaftarkan saham di pasar modal 
diwajibkan untuk laporan keuangannya diaudit oleh Akuntan (Kantor Akuntan Publik) yang erat kaitannya dengan salah satu prinsip tata kelola perusahaan yaitu transparansi. Laporan keuangan yang diaudit oleh auditor KAP the big four dianggap lebih berkualitas karena auditor KAP the big four mampu memitigasi adanya praktik manajemen laba dibandingkan dengan auditor KAP kecil, KAP besar lebih berpengalaman dalam melakukan tugas audit, memiliki sumber daya yang besar sehingga dapat menjalankan tugas audit dengan efektif, efisien dan lebih cepat DeAngelo,(1981); Ebrahim (2001); Riyatno (2007); Annisah dan Kurniasih (2012), sehingga Auditor diharapkan mampu meningkatkan akurasi dan ketepatan perhitungan pajak yang dilakukan oleh manajemen perusahaan sehingga dapat memitigasi adanya praktik penghindaran pajak yang dilakSukan oleh manajemen. Hasil penelitian yang dilakukan oleh Kanagaretnam et al.,(2010) menunjukkan bahwa ada hubungan negatif antara reputasi KAP terhadap manajemen laba di perusahaan perbankan Internasional. Hasil penelitian Anissa (2012), Fadhila (2014); Handayani (2015) menunjukkan bahwa reputasi KAP tidak berpengaruh terhadap tax avoidance, sementara Khoirunnisa (2014); Winata (2014) menunjukkan bahwa reputasi KAP berpengaruh terhadap tax avoidance.

Transaparansi dalam tata kelola perusahaan menjelaskan adanya pengungkapan yang akurat atas laporan keuangan yang diaudit oleh KAP. Hal-hal yang berhubungan dengan kualitas audit menurut Dies (2007) diantaranya: (a) lamanya auditor/umur audit, semakin lama maka semakin rendah kualitas auditnya; (b) jumlah klien yang artinya semakin banyak maka semakin baik kualitas auditnya; (c) kondisi keuangan klien yang artinya bahwa semakin sehat maka ada kecenderungan klien menekan auditor untuk mengikuti standar yang berlaku; serta (d) riview oleh pihak ketiga yang artinya bahwa kualitas audit semakin tinggi apabila diriview oleh pihak ketiga. Sartori (2010) menjelaskan bahwa peningkatan transparansi terhadap pemegang saham dalam hal pajak semakin dituntut oleh otoritas publik, oleh karena itu manajemen perusahaan perlu melaporkan hal-hal terkait perpajakan pada pasar modal dan pertemuan para pemagang saham berdasarkan hasil audit yang dikeluarkan oleh auditor eksternal sehingga mencerminkan adanya pengungkapan yang akurat. Hasil penelitian yang dilakukan oleh Annisa (2011); Jaya dkk (2014), dan Handayani dkk, (2015) menunjukkan bahwa kualitas audit tidak berpengaruh terhadap tax avoidance. Sementara hasil penelitian yang dilakukan oleh Annisa dan Kurniasih (2012) menunjukkan bahwa kualitas audit berpengaruh terhadap tax avoidance.

Komisaris

independen digambarkan sebagai seseorang yang tidak memiliki hubungan dengan direksi atau dewan komisaris, tidak merangkap jabatan, serta tidak terlibat dengan pemegang saham pengendali. Semakin tinggi persentase komisaris independen maka independensi akan semakin tinggi sehingga kebijakan praktik penghindaran pajak akan semakin rendah. Sebaliknya, semakin rendah persentase komisaris independen maka akan mempengaruhi rendahnya indepensi sehingga memberikan peluang akan kebijakan praktik penghindaran pajak yang semakin tinggi. Hasil penelitian yang dilakukan oleh Annisa (2011); Fadhilah (2011); Handayani (2015) menunjukkan bahwa komisaris independen tidak berpengaruh terhadap tax avoidance, sementara hasil penelitian yang dilakukan oleh Bernard (2011); Kurniasih dan Sari (2013), Maharani dan Suardana (2014); Prakosa (2014); Khoirunnisa (2014); Winata (2014); Rachmithasari (2015) menunjukkan bahwa komisaris independen memiliki pengaruh negatif terhadap tax avoidance.

Komite audit adalah susunan komite yang dibentuk oleh dewan komisaris perusahaan yang bertugas membantu dalam melakukan pengauditan atas pelaksanaan fungsi direksi dalam mengelola perusahaan yaitu menelaah risiko yang dihadapi perusahaan, ketaatan terhadap peraturan, serta pengawasan terhadap kinerja perusahaan, sehingga dengan adanya komite audit maka dapat mengurangi tindakan melanggar aturan (Sialllagan dan Machfoedz, 2006). 
Semakin banyak jumlah komite audit maka kebijakan praktik penghindaran pajak akan semakin rendah, sebaliknya semakin sedikit jumlah komite audit maka kebijakan praktik penghindaran pajak akan semakin tinggi. Penelitian yang dilakukan oleh Kurniasih dan Sari (2013), Khoirunnisa (2014); Prakosa (2014); Handayani dkk (2015) menemukan bahwa komite audit tidak berpengaruh berpengaruh terhadap tax avoidance, sementara hasil penelitian yang dilakukan oleh Fadhilah (2011) dan Anissa (2012), Annisa dan Kurniasih (2012); Dewi dan Jati (2014); Maharani dan Suardana (2014); Winata (2014); Rachmithasari (2015) menunjukkan bahwa komite audit berpengaruh negatif terhadap tax avoidance. Berdasarkan uraian diatas, maka hipotesis yang diajukan adalah:

H1a: Reputasi KAP berpengaruh negatif terhadap taxavoidance

H1b: Kualitas audit berpengaruh negatif terhadap taxavoidance

$\mathrm{H} 1 \mathrm{c}$ : Komisaris independen berpengaruh negatif terhadap taxavoidance

H1d: Komite audit berpengaruh negatif terhadap taxavoidance

\section{Tax Avoidance, Komisaris Independen, Komite Audit dan Audit Delay}

Proses perumusan penghindaran pajak hingga tahap akhir membutuhkan waktu yang relatif tidak singkat dikarenakan banyak regulasi yang mengatur tentang perpajakan secara khusus sehingga membutuhkan strategi yang baik. Praktik penghindaran pajak merupakan salah satu bentuk pengelolaan laba yang dilakukan dengan cara menyesuaikan laba kena pajak sesuai dengan yang diinginkan perusahaan. Chai dan Tung (2002) menjelaskan bahwa pengelolaan laba merupakan salah satu faktor yang dapat mempengaruhi waktu penyampaian laporan keuangan tahunan yang disebabkan karena pengelolaan laba membutuhkan proses perumusan yang relatif lama.

Dengan adanya struktur perusahaan yang rumit dan dapat digunakan untuk menutupi aktivitas rent diversion menyebabkan auditor eksternal menjadi lebih teliti dalam mengaudit laporan keuangan perusahaan sehingga dibutuhkan waktu yang relatif lama mengingat audit yang lebih cermat akan meningkatkan kredibilitas informasi keuangan yang diaudit (Crabtree dan Kubick, 2014). Fama dan Jensen (2003) dalam Naimi (2010) menjelaskan bahwa anggota dewan komisaris yang berasal dari luar memiliki insentif untuk melaksanakan tugas- tugas mereka dan tidak berkolusi dengan para manajer untuk menipu pemegang saham karena "there is substantial devaluation of human capital when internal controls break down" (p.35). Dengan adanya dewan komisaris independen diharapkan dapat mengawasi tindakan oportunistik manajamen dan meningkatkan kualitas pengungkapan dalam laporan keuangan serta mengurangi manfaat atas asimetri informasi. Duchin (2010) menjelaskan bahwa dewan komisaris independen diyakini dapat melindungi kepentingan seluruh pemegang saham. Hasil penelitian yang dilakukan oleh Swami dan Latrini (2013) menunjukan bahwa komisaris independen berpengaruh negatif terhadap audit report lag. Sementara, Swarni dan Raharja (2013) menemukan bahwa komisaris independen tidak berpengaruh terhadap audit report lag.

Adanya komite audit, diharapkan dapat membangun kepercayaan publik serta dapat meningkatkan kualitas audit karena pengelolaan perusahaan harus diawasi dan dikendalikan untuk memastikan bahwa pengelolaan telah dilakukan sesuai dengan ketentuan peraturan yang berlaku. Naimi (2010) menunjukkan bahwa semakin besar ukuran komite audit maka akan semakin meningkatkan kualitas pengawasan sehingga dapat memitigasi audit delay. Swami dan Latrini (2013) menunjukan bahwa komite audit berpengaruh negatif terhadap audit report lag. Sementara Whardhani dan Raharja (2013) menunjukkan bahwa komite audit tidak berpengaruh terhadap audit report lag. Berdasarkan uraian tersebut, maka hipotesis yang diajukan adalah:

H2a: Tax avoidance berpengaruh positif terhadap audit delay 
$\mathrm{H} 2 \mathrm{~b}$ : Komisaris independen berpengaruh negatif terhadap audit delay

H2c: Komite audit berpengaruh negatif terhadap audit delay

Tax Avoidance, Komisaris Independen, Komite Audit dan Nilai Perusahaan

Penelitian-penelitian terdahulu mencoba menjelaskan pengaruh praktik penghindaran pajak terhadap nilai perusahaan diantaranya (Desai dan Dharmapala,2009; Wang, 2010; Tang, 2008; Hanlon, 2005; Hanlon dan Slemrod, 2009; Martani, 2010). Dari hasil penelitian terdahulu yang telah diungkapkan di atas menunjukkan bahwa pengaruh praktik penghindaran pajak terhadap nilai perusahaan dapat berdampak negatif maupun positif. Pemegang saham dapat menyetujui praktik penghindaran pajak yang dilakukan oleh manajemen perusahaan apabila memperoleh manfaat yang lebih besar bila dibandingkan biaya yang dikeluarkan. Selain itu juga, pajak merupakan salah satu faktor penting dalam pengambilan keputusan perusahaan. Hasil penelitian yang dilakukan oleh Wang (2010); Martani (2010) menunjukkan bahwa tax avoidance berpengaruh terhadap nilai perusahaan.

Dewan komisaris independen memegang peranan penting terutama dalam pelaksanaan tata kelola perusahaan. Dewan komisaris diharapkan dapat menjamin strategi perusahaan, mengawasi manajer dalam mengelola perusahaan serta mewajibkan tercapainya pelaksanaan akuntabilitas. Hubungan antara jumlah anggota dewan komisaris dengan nilai perusahaan didukung oleh perspektif fungsi kontrol dan service sehingga dewan komisari dapat memberikan konsultasi kepada manajemen perusahaan dan mengontrol perilaku opportunistik manajemen demi menyelaraskan kepentingan prinsipal dan agen (Young et al., 2001). Hasil penelitian yang dilakukan oleh Lastanti (2004) menunjukkan bahwa komisaris independen berpengaruh positif terhadap nilai perusahaan, sementara Febryana (2008) menunjukkan bahwa komisaris independen tidak berpengaruh terhadap nilai perusahaan.
Kualitas komite audit dapat dicapai ketika adanya transparansi atas pertanggungjawaban manajemen perusahaan, sehingga akan meningkatkan kepercayaan publik. Selain itu juga, komite audit memiliki tanggungjawab dalam melindungi kepentingan pemegang saham minoritas atas investasi yang dilakukan terhadap perusahaan tersebut. Hasil penelitian yang dilakukan oleh Siallagan dan Machfoeds (2006) menunjukkan bahwa komite audit berpengaruh positif terhadap nilai perusahaan, sementara Anggraini (2013) menunjukkan bahwa komite audit tidak berpengaruh terhadap nilai perusahaan. Berdasarkan uraian diatas, maka hipotesis yang diajukan adalah:

H3a : Tax avoidance berpengaruh positif terhadap nilai perusahaan

H3b : Komisaris independen berpengaruh positif terhadap nilai perusahaan

H3c : Komite audit berpengaruh positif terhadap nilai perusahaan

\section{METODE PENELITIAN}

\section{Pengumpulan Data dan Pemilihan Sampel}

Jenis data dalam penelitian ini adalah data sekunder berupa laporan keuangan perusahaan perbankan periode 20102014. Metode observasi non partisipan digunakan untuk mencatat data yang diakses melalui situs BEI dan website setiap perusahaan. Dengan menggunakan metode purposive sampling maka diperolah 24 perusahaan dengan periode pengamatan 5 tahun, maka total sampel sebanyak 130 observasi dan setelah dikurangi data outlier, sehingga sampel akhir sebanyak 125 observasi.

Alasan dipilihnya sektor perbankan sebagai sampel adalah (1) perusahaan perbankan di Indonesia diatur secara ketat dalam melaksanakan kegiatan operasionalnya, (2) perbankan dimonitor oleh Bank Sentral (Bank Indonesia) dan badan pengawas lainnya, serta (3) bank merupakan industri keuangan yang bersifat capital intensive dan memiliki risiko usaha tinggi karena dengan 
gagalnya perusahaan perbankan maka dapat menjatuhkan perekonomian negara tersebut.

\section{Definisi Operasional dan Pengukuran Variabel}

Dalam penelitian ini reputasi KAP diukur dari besar kecilnya KAP yang dibedakan dalam dua kelompok, yaitu KAP yang berafiliasi dengan The Big Four dan KAP yang tidak berafiliasi dengan The Big Four. KAP yang berafiliasi dengan The Big Four yaitu Pricewaterhouse Coopers berafiliasi dengan Haryanto Sahari \& Rekan; Ernst \& Young berafiliasi dengan Purwanto, Sarwoko \& Sandjaja; Deloitte berafiliasi dengan Osman Ramli Satrio \& Rekan; KPMG berafiliasi dengan Siddharta \& Widjaya; dan KAP yang tidak berafiliasi dengan The Big Four. Jika perusahaan diaudit oleh KAP The Big Four maka diberi nilai (1), sebaliknya jika perusahaan KAP Non The Big Four maka diberi nilai (0). Kualitas audit diukur dengan model earnings surprise bencmark (Carey dan Simmnett, 2006) dengan ROA sebagai penentu kualitas audit apakah terdapat dalam benchmark atau tidak. Benchmark-nya adalah $\mu-\sigma<$ ROA < $\mu+\sigma, \mu$ adalah rata-rata $\mathrm{ROA}$ seluruh perusahaan sampel dan $\sigma$ adalah deviasinya. ROA yang masuk dalam benchmark menandakan kualitas audit yang baik (1). Sedangkan kualitas audit di asumsikan buruk atau tidak baik (0) apabila: (1) Laba melebihi earnings benchmark yaitu ketika nilai ROA > $\mu+\sigma$, yang diartikan bahwa auditor memberi kesempatan kepada perusahaan untuk melakukan praktik "windows dressing" (adalah usaha manajemen untuk membuat laporan keuangan menjadi"bagus" dengan meningkatkan laba sehingga manajemen dapat menikmati bonus dimasa kini). (2) Rugi melebihi earnings benchmark yaitu ketika nilai ROA $<\mu-\sigma$, yang diartikan bahwa auditor memberi kesempatan perusahaan untuk melakukan praktik "taking a bath" (adalah usaha manajemen untuk membuat laporan keuangan menjadi "jelek" dengan meningkatkan rugi dengan harapan manajemen akan mendapat bonus dimasa depan karena laba yang meningkat). Sehingga dapat dirumuskan variabel dependen kualitas audit (MEET_BE) sebagai berikut:

(a) MEET_BE = 1, ketika memenuhi kriteria $\mu-\sigma<$ ROA $<\mu+\sigma$, menunjukkan kualitas audit yang tinggi

(b) MEET_BE $=0$ untuk ROA $>\mu+\sigma$, dimana manajemen melakukan praktik "windows dressing" atau ROA < $\mu-\sigma$, dimana manajemen melakukan praktik "taking a bath", yang menunjukkan kualitas audit yang rendah.

Komisaris independen diukur dengan total komisaris independen dibandingkan dengan total komisaris dikalikan 100\%. Komite audit diukur dengan total komite audit yang ada di perusahaan sampel. Tax avoidance adalah upaya penghematan pajak dengan memanfaatkan ketentuan perpajakan yang dilakukan secara legal untuk meminimalkan kewajiban pajak (Lim, 2011). Dalam penelitian ini, tax avoidance diukur dengan GAAP ETR (effective tax rate) yang diperoleh dari hasil perbandingan antara beban pajak dengan laba sebelum pajak. Ashton et al., (1997) menjelaskan bahwa audit delay merupakan lamanya waktu penyelesaian audit dimulai dari akhir tahun fiscal perusahaan sampai tanggal laporan audit dikeluarkan. Audit delay dalam penelitian ini diukur dengan tanggal laporan auditor independen dikurangi tanggal tahun buku perusahaan yang berakhir dalam jumlah hari. Nilai perusahaan merupakan persepsi investor terhadap tingkat keberhasilan perusahaan yang sering dikaitkan dengan harga saham (Sujoko dan Soebiantoro, 2007). Nilai perusahaan dalam penelitian ini diukur dengan Return on Asset yang diperoleh dari laporan keuangan tahunan perusahaan sampel. Agar model regresi tidak bias (BLUE), maka diperlukan uji asumsi klasik terlebih dahulu yang terdiri atas uji normalitas, uji multikolinearitas, uji heteroskedastisitas, dan uji autokorelasi (Gujarati, 2003).

Uji normalitas digunakan untuk mengetahui apakah residual memiliki distribusi normal. Model regresi yang baik adalah yang mempunyai data berdistribusi normal atau mendekati normal. Dalam pengujian ini digunakan one sample Kolmogorov-smirnov. Data dikatakan berdistribusi normal jika 
signifikansi berada diatas 5\% (Gujarati, 2003). Uji multikolinearitas bertujuan untuk menguji apakah dalam model regresi ditemukan adanya korelasi antar variabel independen. Model regresi yang baik adalah model yang tidak terjadi korelasi antara variable independen. Pengambilan keputusan mengenai ada tidaknya korealsi antarvariabel independen yaitu dengan melihat nilai tolerance dan nilai variance inflation factor. Gujarati (2003) mengatakan bahwa jika nilai tolerance lebih dari 0,1 dan nilai VIF yang tidak lebih dari 10 maka hubungan linear diantara variabel bebas dalam model regresi tidak mengandung multikolinearitas. Uji heteroskedastisitas bertujuan untuk mengetahui apakah model regresi terjadi ketidaksamaan variance residual dari suatu pengamatan ke pengamatan yang lain. Jika variance residual dari suatu pengamatan ke pengamatan yang lain tetap maka disebut homokedastisitas dan jika berbeda disebut heteroskedastisitas. Model regresi yang baik adalah model regresi yang memenuhi asumsi homokedastisitas. Uji heteroskedastisitas dilakukan dengan uji glejser. Uji glejser dilakukan dengan mengabsolutkan nilai residual regresi dan menggunakan absolut tersebut sebagai variabel dependen. Pengujiannya dengan melihat signifikansi hasil dari regresi dengan absolut residual sebagai variabel dependen. Masalah heteroskedastisitas akan terjadi bila masing- masing variabel independen mempunyai nilai signifikansi lebih kecil dari alpha 0,05 (Gujarati, 2003). Uji autokorelasi bertujuan untuk menguji apakah dalam model regresi linear ada korelasi antara kesalahan penganggu pada periode $t$ dengan kesalahan pengganggu pada periode $\mathrm{t}-1$ (sebelumnya). Jika terjadi korelasi, maka ada masalah autokorelasi. Autokorelasi muncul karena observasi yang berurutan sepanjang waktu berkaitan satu sama lainnya. Masalah ini timbul karena residual (kesalahan pengganggu) tidak bebas dari satu observasi ke observasi lainnya. Pengambilan keputusan mengenai ada tidaknya autokorelasi adalah sebagai berikut: jika nilai DurbinWatson diperoleh berada diantara -2 sampai dengan 2 maka diasumsikan tidak ada autokorelasi (Santoso, 2010).

Dalam penelitian ini, pengujian hipotesis menggunakan model regresi linear berganda yang diuji secara bertahap. Regresi linear berganda digunakan untuk menguji hubungan corporate governance dengan tax avoidance serta pengaruhnya terhadap audit delay dan nilai perusahaan. Adapun persamaan matematis untuk pengujian hipotesis dalam penelitian adalah sebagai berikut:

Persamaan Model 11

Y1TAXA $=\alpha+\beta 1$ REPUTASI $+\beta 2 \mathrm{KUAL}^{+}+\beta 3 \mathrm{KI}^{+}$ $\beta 3 \mathrm{KA}+\mathrm{e}$

Persamaan Model 2

$\mathrm{Y} 2 \mathrm{AUDL}=\alpha+\beta 1 \mathrm{TAXA}+\beta 2 \mathrm{KI}+\beta 3 \mathrm{KA}+\mathrm{e} 2$

Persamaan Model 3

$\mathrm{Y} 3 \mathrm{NP}=a+\beta 1 \mathrm{TAXA}+\beta 2 \mathrm{KI}+\beta 3 \mathrm{KA}+\mathrm{e} 3$

\section{PEMBAHASAN}

\section{Analisis Statistik Deskriptif}

Jumlah seluruh perusahaan perbankan yang terdaftar dari tahun 2010-2014 sebanyak 30 perusahaan. Sesuai dengan kriteria pengambilan sampel yang telah disebutkan sebelumnya maka terdapat beberapa perusahaan yang harus dikeluarkan dari sampel. Sampel akhir dari penelitian ini berjumlah 26 perusahaan dengan total 130 observasi.

\section{Pengujian Asumsi Klasik}

Hasil pengujian normalitas data dengan One Sample Kolmogorov-Smirnov Test, menunjukkan hasil yang tidak signifikan, yaitu lebih besar dari 0.05 (5\%), sehingga pada masing-masing variabel yang digunakan dalam penelitian ini, memiliki pola distribusi data yang normal. Hasil pengujian menunjukkan bahwa model yang dipergunakan dalam penelitian ini tidak terdapat masalah multikolinearitas. Hal tersebut ditunjukkan dengan adanya nilai tolerance diantara dua variabel independen yang lebih besar dari 0.01 dan nilai VIF yang lebih kecil dari 10 . Hasil pengujian heteroskedastisitas dengan Uji One glejser, menunjukkan hasil yang tidak signifikan, yaitu lebih besar dari 0.05 (5\%), sehingga pada masing-masing variabel yang digunakan 
dalam penelitian ini memiliki data yang homokedastisitas. Selanjutnya hasil pengujian autokorelasi dengan Uji Durbin-Watson menunjukkan bahwa nilai DW statistik masih dalam batas toleransi seperti terlihat yaitu berkisar antara -2 sampai dengan 2 .

\section{Pengujian Hipotesis}

Pengujian hipotesis untuk model persamaan I menggunakan model regresi linear berganda yang digunakan untuk menguji pengaruh reputasi KAP, kualitas audit, komisaris independen dan komite audit terhadap tax avoidance. Uji ANOVA menghasilkan nilai $F$ hitung sebesar 3.808 dengan probabilitas signifikansi sebesar $0.006 \quad(\mathrm{p}<0.05)$. Hal ini menunjukkan bahwa model penelitian memenuhi goodness of fit. Selanjutnya, berdasarkan hasil analisis persamaan I diperoleh nilai $\mathrm{R}$ square sebesar 0.113. Hal ini berarti $11.3 \%$ variasi tax avoidance dapat dijelaskan oleh variasi reputasi KAP, kualitas audit, komisaris independen dan komite audit, sedangkan sisanya sebesar $88.7 \%$ dijelaskan oleh faktor-faktor lain diluar model. Selanjutnya, hasil pengujian hipotesis 1a menunjukkan bahwa reputasi KAP tidak berpengaruh negatif terhadap tax avoidance. Hasil regresi tersebut memiliki nilai t-test sebesar -0.282 dengan tingkat signifikansi hasil pengujian sebesar 0.778 lebih besar dibandingkan dengan tingkat signifikansi yang digunakan dalam penelitian ini, yaitu sebesar 0.05 (5\%). Hasil pengujian hipotesis $1 \mathrm{~b}$ menunjukkan bahwa kualitas audit tidak berpengaruh negatif dan signifikan terhadap tax avoidance. Hasil regresi tersebut memiliki nilai t-test sebesar 0.838 dengan tingkat signifikansi hasil pengujian sebesar 0.404 lebih besar dibandingkan dengan tingkat signifikansi yang digunakan dalam penelitian ini, yaitu sebesar 0.05 (5\%). Hasil pengujian hipotesis 1c menunjukkan bahwa komisaris independen berpengaruh negatif terhadap tax avoidance. Hasil regresi tersebut memiliki nilai t-test sebesar -3.635 dengan tingkat signifikansi hasil pengujian sebesar 0.000 lebih kecil dibandingkan dengan tingkat signifikansi yang digunakan dalam penelitian ini, yaitu sebesar 0.05 (5\%). Hasil pengujian hipotesis 1d menunjukkan bahwa komite audit tidak berpengaruh negatif dan signifikan terhadap tax avoidance. Hasil regresi tersebut memiliki nilai t-test sebesar 0.113 dengan tingkat signifikansi hasil pengujian sebesar 0.910 lebih besar dibandingkan dengan tingkat signifikansi yang digunakan yaitu 0.05 (5\%).

Pengujian hipotesis untuk model persamaan II menggunakan model regresi linear berganda yang digunakan untuk menguji pengaruh pengaruh tax avoidance, komisaris independen dan komite audit terhadap audit delay. Uji ANOVA, menghasilkan nilai $F$ hitung sebesar 4.512 dengan probabilitas signifikansi sebesar $0.005(\mathrm{p}<0.05)$. Hal ini menunjukkan bahwa model penelitian memenuhi goodness of fit. Selanjutnya, hasil analisis persamaan II diperoleh nilai $\mathrm{R}$ square sebesar 0.101 hal ini berarti $10.1 \%$ variasi audit delay dapat dijelaskan oleh variasi tax avoidance, komisaris independen dan komite audit, sedangkan sisanya sebesar 89.9\% dijelaskan oleh faktor-faktor lain diluar model. Hasil pengujian hipotesis $2 \mathrm{a}$ menunjukkan bahwa tax avoidance tidak berpengaruh negatif dan signifikan terhadap audit delay. Hasil regresi tersebut memiliki nilai t-test sebesar 0.810 dengan tingkat signifikansi hasil pengujian sebesar 0.419 lebih besar dibandingkan dengan tingkat signifikansi yang digunakan dalam penelitian ini, yaitu sebesar 0.05 (5\%). Hasil pengujian hipotesis 2b menunjukkan bahwa komisaris independen tidak berpengaruh negatif dan signifikan terhadap audit delay. Hasil regresi tersebut memiliki nilai t-test sebesar 1.694 dengan tingkat signifikansi hasil pengujian sebesar 0.093 lebih besar dibandingkan dengan tingkat signifikansi yang digunakan dalam penelitian ini, yaitu sebesar 0.05 (5\%). Hasil pengujian hipotesis 2c menunjukkan bahwa komite audit berpengaruh negatif dan signifikan terhadap audit delay. Hasil regresi tersebut memiliki nilai t-test sebesar 3.366 dengan tingkat signifikansi hasil pengujian sebesar 0.001 lebih kecil dibandingkan dengan tingkat signifikansi yang digunakan dalam penelitian ini, yaitu sebesar 0.05 (5\%).

Pengujian hipotesis untuk model persamaan III menggunakan model 
regresi linear berganda untuk menguji pengaruh pengaruhtax avoidance, komisaris independen, dan komite audit terhadap nilai perusahaan. Uji ANOVA, menghasilkan nilai $F$ hitung sebesar 8.324 dengan probabilitas signifikansi sebesar $0.000 \quad(p<0.05)$. Hal ini menunjukkan bahwa model penelitian memenuhi goodness of fit. Selanjutnya, hasil analisis persamaan III diperoleh nilai $\mathrm{R}$ square sebesar 0.171 . Hal ini berarti $17.1 \%$ variasi nilai perusahaan dapat dijelaskan oleh variasi tax avoidance, komisaris independen dan komite audit, sedangkan sisanya sebesar $79.2 \%$ dijelaskan oleh faktorfaktor lain diluar model. Hasil pengujian hipotesis 3a menunjukkan bahwa tax avoidance berpengaruh negatif dan signifikan terhadap nilai perusahaan. Hasil regresi tersebut memiliki nilai t-test sebesar -2.531 dengan tingkat signifikansi hasil pengujian sebesar 0.013 lebih kecil dibandingkan dengan tingkat signifikansi yang digunakan dalam penelitian ini, yaitu sebesar 0.05 (5\%). Hasil pengujian hipotesis $3 \mathrm{~b}$ menunjukkan bahwa komisaris independen tidak berpengaruh positif dan signifikan terhadap nilai perusahaan. Hasil regresi tersebut memiliki nilai t-test sebesar 0.093 dengan tingkat signifikansi hasil pengujian sebesar 0.926 lebih besar dibandingkan dengan tingkat signifikansi yang digunakan dalam penelitian ini, yaitu sebesar $0.05(5 \%)$. Hasil pengujian hipotesis $3 \mathrm{c}$ menunjukkan bahwa komite audit berpengaruh positif dan signifikan terhadap nilai perusahaan. Hasil regresi tersebut memiliki nilai t- test sebesar 3.988 dengan tingkat signifikansi hasil pengujian sebesar 0.000 lebih kecil dibandingkan dengan tingkat signifikansi yang digunakan dalam penelitian ini, yaitu sebesar 0.05 (5\%).

Hipotesis 1a yang menyatakan bahwa reputasi KAP mempunyai pengaruh negatif terhadap tax avoidance secara empiris tidak terdukung. Hal ini menunjukkan bahwa audit yang dilakukan oleh auditor baik itu yang bereputasi (berafliasi dengan The Big Four) maupun yang tidak bereputasi (tidak berafiliasi dengan non The Big
Four) tidak memiliki perbedaan yang signifikan dalam memitigasi terjadinya praktik tax avoidance, karena auditor dalam mengaudit laporan keuangan klien telah menggunakan standar yang telah ditentukan oleh Dewan Standar Profesional Akuntan Publik Indonesia dan aturan etika akuntan publik yang ditetapkan oleh IAPI. Hasil penelitian ini konsisten dengan hasil penelitian yang dilakukan oleh Winata (2014) dan Fadhila (2014).

Hipotesis $1 \mathrm{~b}$ yang menyatakan bahwa kualitas audit mempunyai pengaruh negatif terhadap tax avoidance secara empiris tidak terdukung. Hal ini mengindikasikan bahwa Indonesia sebagai suatu negara yang menganut sistem pemungutan pajak berdasarkan self assesment memberikan kepercayaan kepada wajib pajak untuk menghitung, menyetor dan melaporkan pajak terutang sesuai dengan ketentuan perpajakan yang berlaku sehingga dibutuhkan kesadaran moral dalam membayar pajak yang disebut sebagai moralitas perpajakan (Lasmana dan Tjaraka, 2011). Moralitas perpajakan memcerminkan suatu kesadaran (jujur) yang timbul dari wajib pajak ketika membayar pajak. Lebih lanjut, moralitas yang dimiliki oleh seseorang (wajib pajak) turut mempengaruhi perilaku wajib pajak dalam melakukan penghindaran pajak tanpa melihat hasil audit laporan keuangan perusahaan sebagai pertimbangan dalam melakukan penghindaran pajak (Jaya dkk, 2014). Hasil penelitian ini konsisten dengan hasil penelitian yang dilakukan oleh Jaya dkk (2014) dan Handayani dkk (2015).

Hipotesis 1c yang menyatakan bahwa komisaris independen mempunyai pengaruh negatif terhadap tax avoidance secara empiris terdukung. Hal ini menunjukkan bahwa apabila komposisi komisaris independen mengalami peningkatan maka praktik penghindaran pajak dapat dimitigasi karena komisaris independen merupakan pihak luar yang tidak terafiliasi dengan pihak manajemen perusahaan serta pemegang saham pengendali, dan telah menjalankan fungsi pengawasan atas perumusan strategi perusahaan dalam kaitannya dengan pajak dengan cukup baik. Hasil penelitian ini konsisten dengan hasil 
penelitian yang dilakukan oleh Bernard (2011); Kurniasih dan Sari (2013), Maharani dan Suardana (2014); Prakosa (2014); Khoirunnisa (2014); Winata (2014) dan Rachmithasari (2015).

Hipotesis 1d yang menyatakan bahwa komite audit mempunyai pengaruh negatif terhadap tax avoidance secara empiris tidak terdukung. Hal ini menunjukkan bahwa jumlah anggota komite audit yang banyak maupun sedikit tidak memberikan jaminan bahwa praktik tax avoidance dapat dihindari dalam menentukan kebijakan yang berhubungan dengan tarif pajak efektif bagi perusahaan.

Hipotesis 2a yang menyatakan bahwa tax avoidance memiliki pengaruh positif terhadap audit delay secara empiris tidak terdukung. Hal ini menunjukkan bahwa perencanaan pajak yang dirancang oleh manajemen perusahaan secara permanen untuk memitigasi adanya kewajiban pajak perusahaan dalam membantu perusahaan untuk memenuhi ekspektasi pasar tidak membutuhkan waktu yang cukup lama, sehingga tidak berdampak pada keterlambatan pengumuman laporan keuangan tahunan, karena hal ini terjadi mengingat pengumuman laba tahunan mengandung informasi yang dibutuhkan oleh stakeholders dalam pengambilan keputusan. Selain itu juga, laporan keuangan tahunan merupakan sumber informasi yang penting bagi stakeholders karena memiliki tingkat reliabilitas tinggi. Hasil penelitian ini tidak mendukung hasil penelitian yang dilakukan oleh Brian dan Martani (2014) dan Crabtree dan Kubick (2014).

Hipotesis 2b yang menyatakan bahwa komisaris independen mempunyai pengaruh negatif terhadap audit delay secara empiris tidak terdukung. Hal ini berarti bahwa walaupun dengan adanya komisaris independen dalam susunan komisaris, namun belum mampu untuk memitigasi terjadinya audit delay karena belum mampu untuk mengawasi perilaku oportunistik manajemen, selain itu juga, bisa saja fungsi komisaris independen hanya sebatas mematuhi regulasi yang ditetapkan oleh Bapepam (sekarang OJK). Hasil penelitian ini konsisten dengan hasil penelitian yang dilakukan oleh Purwati (2006); dan
Wardhani dan Raharja (2013).

Hipotesis 2c yang menyatakan bahwa komite audit mempunyai pengaruh negatif terhadap audit delay secara empiris terdukung. Hal ini berarti bahwa dengan adanya komite audit maka dapat membangun kepercayaan publik dalam pelaporan keuangan serta dapat mencegah atau mendeteksi adanya salah saji material, sehingga dapat memitigasi terjadinya keterlambatan penyampaian laporan keuangan tahunan (audit delay) yang berdampak pada kualitas audit. Hasil penelitian konsisten dengan hasil penelitian yang dilakukan oleh Swami dan Latrini (2013).

Hipotesis $3 a$ yang menyatakan bahwa tax avoidance mempunyai pengaruh positif terhadap nilai perusahaan secara empiris terdukung. Hal ini menunjukkan bahwa dengan adanya praktik tax avoidance yang dilakukan oleh manajemen perusahaan maka dapat meningkatkan nilai perusahaan, sehingga dapat memakmurkan para pemegang saham karena mereka umumnya menyetujui tindakan tersebut ketika adanya benefit yang akan diterima atas praktik tax avoidance bila dibandingkan dengan diaya yang dikeluarkan. Hasil penelitian ini konsisten dengan hasil penelitian yang dilakukan oleh Chasbiandani dan Martani (2013).

Hipotesis $3 \mathrm{~b}$ yang menyatakan bahwa komisaris independen berpengaruh positif terhadap nilai perusahaan secara empiris tidak terdukung. Hal ini menunjukkan bahwa komisaris independen belum optimal memonitor kinerja manajemen, sehingga proporsi dewan komisaris indepnden belum mampu meningkatkan nilai perusahaan. Hal ini mungkin disebabkan karena adanya kendali penuh yang pemilik saham mayoritas yang menjadikan komisaris independen tidak dapat menjalankan fungsinya dengan efektif. Hasil penelitian ini konsisten dengan hasil penelitian yang dilakukan oleh Bangun dan Vincent (2008) dan Sari dan Ridwan (2013).

Hipotesis 3c yang menyatakan bahwa komite audit berpengaruh positif terhadap nilai perusahaan secara empiris terdukung. Hal ini menunjukkan bahwa komite audit mampu memainkan 
peranan penting dalam hal indepndensi fungsi audit, adanya transparansi pertanggungjawaban manajemen perusahaan, sehingga akan meningkatkan kepercayaan publik dan berdampak pada kenaikan nilai perusahaan. Hasil penelitian ini konsisten dengan hasil penelitian yang dilakukan oleh Kwatu (2007) dan Herawaty (2008).

\section{PENUTUP}

\section{Simpulan}

Berdasarkan analisis data di atas maka hasil penelitian menunjukkan bahwa (1) komisaris independen berpengaruh negatif dan signifikan terhadap tax avoidance, sedangkan reputasi KAP, kualitas audit, dan komite audit tidak berpengaruh terhadap tax avoidance; (2) komite audit memiliki pengaruh negatif terhadap audit delay, sedangkan tax avoidance dan komisaris independen tidak berpengaruh terhadap audit delay; (3) tax avoidance dan komite audit memiliki pengaruh terhadap nilai perusahaan, sedangkan komisaris independen tidak berpengaruh terhadap nilai perusahaan. Penelitian ini dapat memberikan sumbangsi bagi Otoritas Jasa keuangan (OJK) selaku regulator pasar modal dalam merumuskan regulasi yang lebih baik. Selain itu juga, penelitian ini memberikan masukan kepada Direktorat Jendral Pajak selaku regulator di bidang perpajakan dalam melakukan evaluasi mengenai laporan keuangan yang disampaikan untuk menjamin pemenuhan kebutuhan pembayaran pajak, mengevaluasi praktik mekanisme corporate governance telah berjalan sesuai dengan regulasi, sehingga dapat meningkatkan nilai perusahaan.

\section{Keterbatasan dan saran}

Keterbatasan dalam penelitian ini adalah (1) hasil penelitian tidak dapat digeneralisasikan untuk perusahaan non perbankan yang terdaftar di Bursa Efek Indonesia, sehingga diharapkan penelitian yang akan datang menggunakan sampel perusahaan yang selain sektor perbankan seperti sektor utama maupun sektor manufaktur; (2) penelitian ini tidak mempertimbangkan faktor-faktor lain yang relevan yang turut mempengaruhi praktik penghindaran pajak, audit delay, dan nilai perusahaan, sehingga diharapkan penelitian selanjutnya menambah variabel seperti kepemilikan keluarga, kompensasi manajemen, dan cost of debt; (3) ukuran sampel yang digunakan dalam penelitian ini relatif kecil karena hanya dibatasi pada sektor perbankan yang telah go public di Indonesia, selain itu juga penggunaan proksi dalam penelitian ini belum mampu menjawab tentang praktik penghindaran pajak yang terjadi dalam perusahaan.

\section{DAFTAR PUSTAKA}

Annisa, N. A. dan Kurniasih, L., (2012). Pengaruh Corporate Governance terhadap Tax Avoidance, Jurnal Akuntansi dan Auditing, Vol. 8, No. 2, Mei: 123-132.

Armstrong, C., Blouin, J., D. Larcker, (2012). The incentives for tax planning. Journal of Accounting and Economics 53(1): 391-411.

Bamber, E. M., Bamber, L.S. and Schoderbek, M. P. (1993). Audit Structure and Other Determinants of Audit Report Lag: An Empirical Analysis. Auditing: A Journal of Practice and Theory, 12/1, p. 1-23.

Brennan, M.J. (1995), Corporate Finance Over the Past 25 Years, Financial Management 24, 9-22.

Chai, M. L., \& Tung, S. (2002). The Effect of Earnings Announcement Timing on Earnings Management. Journal of Business Finance \& Accounting, Vol. 29, Issue 9-10, 1337-1354.

Crabtree, A. D., \& Kubick, T. R. (2014). Corporate Tax Avoidance and The Timeliness of Annual Earnings Announcements. Review of Quantitative Finance and Accounting, Vol. 42, Issue 1, 51-67.

Desai M. A., and D. Dharmapala, (2006). Corporate tax avoidance and high powered incentives. Journal of Financial Economics 79: 145-179.

Friese, A, S. Link, dan S. Mayer. (2006). Taxation and Corporate Governance. Working Paper.

Gujarati, Damodar. (2003). Ekonometrika Dasar : Edisi Keenam. Jakarta: Erlangga. 
Hanlon, Michelle. (2005). The Persistence and pricing of Earnings, Accruals and cash flow when firms have large book tax differences. The Accounting Review. 80 (1), 137 - 166.

Hanlon, Michael, Joel Slemrod. (2009). Waht tax aggressiveness signal? Evidance from stock Price reaction to news about tax selter involvement.Journal of Public Economics 93.Pp $126-141$.

Lim, YD. (2011). Tax avoidance, cost of debt and shareholder activism: Evidence from Korea. Journal of Banking \& Finance 35, 456-470.

Martani, Dwi. Debby Fitriasari dan Yulianti.(2010). Influence of BTD towards earnings persistence and firm value for the period of 1999-2007.The 3rd and 2nd Doctoral Colloquium FE UI. 27-28 Oktober 2010.

Owusu-Ansah, S., (2000). Timeliness of corporate financial reporting in emerging capital markets: Empirical evidence from the Zimbabwe Stock Exchange. Accounting and Business Research, 30(3), pp. 241-254.

Santoso, S. (2010). Statistik Multivariat Konsep dan Aplikasi dengan SPSS.

Jakarta: PT. Elex Media Komputindo.

Shevlin, T. and D. A. Shackelford, 2001. Empirical tax research in accounting. Journal of Accounting and Economics 31: 321-387.

Shevlin, T., (2007). The future of tax research: From an accounting professor's perspective. Journal of the American Taxation Association 29: 87-93.

Siallagan, Hamongan dan Machfoedz, Mas'ud. (2006). Mekanisme Corporate Governance, Kualitas Laba dan Nilai Perusahaan. Simposium Nasional Akuntansi IX, Padang.

Scholes, M. S., Wolfson, M. A., Erickson, M. M., Maydew, E. L., and T. J. Shevlin, (2009). Taxes and business strategy: a planning approach, Prentice Hal 